\title{
Electrochemical biosensors in pharmaceutical analysis
}

\author{
Eric de Souza Gil*, Giselle Rodrigues de Melo
}

Faculty of Pharmacy, Federal University of Goiás

\begin{abstract}
Given the increasing demand for practical and low-cost analytical techniques, biosensors have attracted attention for use in the quality analysis of drugs, medicines, and other analytes of interest in the pharmaceutical area. Biosensors allow quantification not only of the active component in pharmaceutical formulations, but also the analysis of degradation products and metabolites in biological fluids. Thus, this article presents a brief review of biosensor use in pharmaceutical analysis, focusing on enzymatic electrochemical sensors.
\end{abstract}

Uniterms: Biosensors. Pharmaceutical analysis. Electrochemical sensors. Enzymes.

Em virtude do aumento da demanda por técnicas analíticas simples e de baixo custo, os biossensores têm atraído a atenção para a análise de fármacos, medicamentos e outros analitos de interesse em controle de qualidade de medicamentos. Os biossensores permitem a quantificação não somente de princípio ativo em formulações farmacêuticas, mas também de produtos de degradação e metabólitos em fluídos biológicos, bem como análise de amostras de interesse clínico e industrial, além de possibilitar a determinação de enantiômeros. Desta forma, este artigo objetiva fazer uma breve revisão a respeito do emprego de biossensores em análise farmacêutica, com ênfase em sensores eletroquímicos enzimáticos.

Unitermos: Biossensores. Análise farmacêutica. Sensores eletroquímicos. Enzimas.

\section{INTRODUCTION}

Both research and development of pharmaceutical analysis embraces innovative procedures in a bid to combine accuracy, precision, selectivity, and sensitivity with simplicity, rapidity and low cost. Hence, the interest in biosensors has increased over recent years, since such devices consolidate many of these qualities, including simplicity and rapidity. Indeed, due to these characteristics, biosensors have been applied to many fields of chemical analysis including biomedical, pharmaceutical, food and environmental.

Biosensors are composed of two main parts: a biological recognizing component (enzyme, antibody, cell, tissue, etc.) directly connected to a physical transducer (voltammetric, amperometric, conductometric, spectrophotometric, etc) (Kauffman, 2002). The broad variety of biological systems that can be used as recognizing

*Correspondence: E. S. Gil. Faculdade de Farmácia, Universidade Federal de Goiás. Av. Universitária com $1^{a}$ Avenida s/n, Setor Universitário, 74605-220 Goiânia-GO, Brasil. E-mail: ericsgil@gmail.com agents allows specific biosensors for a very large pool of analytes. Furthermore, electrochemical transducers confer high sensitivity for these devices (Lojou, Bianco, 2006).

In spite of some significant disadvantages including low stability and poor reproducibility, which have been an obstacle to biosensor applications in quality control of medicines, the advantages outlined have kept biosensors a scientific focus (Kaufman, 2002).

The physicochemical interaction between analyte and the bio-recognizing agent is monitored by a transducer. In the case of electrochemical biosensors, the signal detection occurs at the electrode/solution interface, which can be dynamic or static. In dynamic methods, i.e. voltammetry (amperometric biosensor), the interaction must involve a redox process followed by electron transfer. In static methods (potentiometry) however, the concentration of charged species, as a function of the electrochemical potential, is monitored by a potentiometric biosensor (Ravishankara, Pillai, Handral, 2001). The use of either biosensor depends on the characteristics of the analyte. Thus, for amperometric biosensors, inorganic or organic species must undergo a redox process at working poten- 
tials, i.e. electroactive species, while static methods are applicable to charged species (Stradiotto et al., 2003). The correct choice of the recognizing agent and transducer, both suited to the target molecule, is the key to achieving an optimum biosensor.

Since the first description of biosensors based on glucose-oxidase, many configurations have been proposed for these devices in an effort to improve transduction mechanisms, molecular recognizing systems and immobilization of biological components (Yu et al., 2005). Among the most widely used recognizing agents are enzymes (e.g. peroxidases, phenoloxidases and sterases), antibodies, drug receptors, and DNA. The use of entire cells or tissues, as well as other components, is less common in biosensors applied to pharmaceutical analysis (Yu et al., 2005).

The level of specificity of the recognizing agent is based not only on the intrinsic structural properties of the biological component, but also on the way that component is immobilized on the transducer, enabling systems capable of discriminating two enantiomers or only one chemical class (Stefan et al., 1999). The transducer system converts a chemical signal into a measurable signal. The transducers can be classified into: potentiometric, amperometric, conductometric, optical, entalpimetric, or piezoelectrical (Pereira et al., 2002). In electrochemical biosensors, the main transducing elements include support electrodes of noble metals (e.g. Pt and $\mathrm{Au}$ ) and carbon derivatives (e.g. glassy carbon, carbon paste). These electrodes can be modified in order to improve the connection with the recognizing agent, being applicable for pharmaceutical and biomedical analysis of a large variety of samples (Nakamura, Karube, 2003; Uslu, Bengi, Sibel, 2007; Oezkan, Uslu, Aboul-Enein, 2003, Uslu et al., 2007).

The substantial advances in materials science and nanotechnology has led to significant development of many electrochemical transducers, such as:

a) Development of conductive polymers with suitable characteristics for electrochemical sensors, for example: ultrathin films, low electrical resistivity and suitable functional groups for immobilization of recognizing agent (Malhotra et al., 2006);

b) Development of carbon nanotubes, which often offer a larger superficial area for signal transduction, as well as for immobilization of enzymes, DNA or even for pre-concentration of electroactive molecules (He, Xu, Fang, 2006).

c) Development of nanomaterial with molecular dimensions, i.e. porous and monodispersive particles of clays with high superficial area, resulting in high sensitivity (10 picomolar) (Mousty, 2004);

d) Development of biomimetic ionophore channels that respond selectively to specific drugs (Kohli, Wirtz, Martin, 2004; Keusgen, 2002).

However, the efficient immobilization of recognizing agents for transducers remains a major challenge in biosensor technology. The optimization of analytical signal involves the suitable immobilization of biological component to the physical component. Many techniques of immobilization have been proposed. Crosslinking between functional polymer groups and bio-components in polymeric matrices, self-assembled monolayer techniques (SAMS), thin co-electropolymerization with electron mediators and conductive systems number some examples of these techniques (Nakamura, Karube, 2003).

The main parameters of immobilization efficiency are the guarantee of selectivity, sensitivity and stability. Biosensor stability is associated with the reproducibility of the response and depends mainly on the binding force between the biological element and the transducer (Nakamura, Karube, 2003). It is worth noting that immobilization allows a favorable environment for the maximum activity of the biological system. The association between enzymes and DNA or other natural polymers has been widely explored. Enzymes and DNA co-immobilization in ultrathin polymeric monolayer has resulted in high sensitivity and selective systems for analytical and pharmacological purposes (Dantoni et al., 1998; Rusling et al., 2008).

The technology of screen-printed electrodes in biosensor development has also received much attention (Nascimento, Angnes, 1998; Freire et al, 2002; Hart, 2004; Soares et al., 2007). Suprun et al (2005), optimized acetylcholinesterase biosensors for detection of carbamates and organophosphorus pesticides by using the screen-printed technique and electron mediators to modify carbon electrodes.

This article presents a brief review of the applications of electrochemical biosensors in pharmaceutical analysis.

\section{BIOSENSORS IN PHARMACEUTICAL ANALYSIS}

Given that the pharmacopeia methods are often timeconsuming and expensive, biosensors have become an interesting alternative. Much research has been carried out towards the optimization of immobilization techniques, and in the obtention of the analytical signal. Novel biological and biomimetic recognizing systems have been explored (Fatibello-Filho, 2007; Lowe, 1999). A few examples of biological recognizing agents coupled with electrochemical transducers include the use of enzyme aryl-acyl-amidase to detect aminophenol delivered from acetaminophen for the indirect analysis of paracetamol samples; the use of 
teophilin oxidase coupled with the electron mediator (ferrocyanate) for theophylline analysis; salicylate hydroxylase for the detection of salicylate in the presence of NADH and oxygen; tyrosinase for analysis of phenolic compound, catecholamines and peroxides (Wang, 1999).

The analytical strategies employed in the development of biosensors range from the detection of a signal generated by the direct interaction between the analyte and the recognizing agent, or indirectly, involving mediators and coupling reactions.

The majority of biosensors are based on enzymatic reactions, whereby the nature of the products in the biochemical reaction, as well as the molecular characteristics of the analyte, determine the best kind of transducer to be utilized (Pereira, Santos, Kubota, 2002).

Concerning oxidizible drugs, the best choice would be amperometric transducers and the enzymes: peroxidases, laccases, tyrosinase, superoxide dismutase, among other oxidases which could be used as the biological component in molecular recognizing (Erdem, 2000; Ferapontova, 2007; Gil, 2009).

Electron transfers from enzymatic reactions to the electrode surface can occur by three mechanisms, defining the type of amperometric biosensor used, which can be classified into three generations:

1) The first generation electrodes are based on the redox behavior of cofactors, $\left(\beta-\mathrm{NAD}(\mathrm{P})^{+}\right.$.).

2) The second generation has incorporated the use of electron mediators in order to reduce potential and improve electron transfer and sensitivity.

3) In the third generation electrodes, the electron transfer occurs directly between the active center of enzyme and electrodic material (Oliveira-Neto et al., 1999).

Regarding drugs containing hydrolysable and labile groups and/or when there is proton $\mathrm{H}^{+}$liberation, the use of ion-selective electrodes or potentiometric biosensors is the most frequently used alternative (Liu et al., 1998; Couto, Montenegro, 2000; Shvedene, Borovskaya, 2003; Ozoemena et al., 2005).

Among the promising perspectives concerning the future of biosensors is the use of biomimetic models, which combine improved chemical stability with similar activity of the respective enzyme (Tan et al., 2001; Kindschy, Alocilja, Evangelyn, 2007).

\section{ANTI-INFLAMMATORY AND ANALGESIC DRUGS}

The drugs belonging to the NSAID (Non Steroidal, Anti-inflammatory Drug) therapeutical class are the most- consumed in the world. They are subdivided into three or more classes, according to selectivity for cyclooxogenase I and II (Goodman, Gilman, 1996). In view of the number of analyses carried out every day, research furthering the development of alternative methods that combine highspeed and simplicity with low cost is justified.

\section{Salicylates}

Due to its simplicity and rapidity, Trinder's method is the most widespread methodology for salicylate analysis. However, this method is subject to interference from enolic and phenolic groups (Gil, 2007; Oliveira-Neto et al., 1999). Moreover, instrumental methods, e.g. High Performance Chromatography (Friederkees, Grobecker, 1996) and UV-spectrophotometry (Kokot, Burda, 1998) are time consuming and require one or more sample preparation steps (Júnior et al., 2000). In this context, electroanalysis and the use of biosensors can be very promising. Given the possibilities of obtaining measurements at low potentials, the use of electron mediators is an interesting option. In addition, the second generation amperometric biosensors are cheaper than other technologies (Moore et al., 1995).

A number of biosensors based on Salicylate Hydroxylase (SH) (EC 1.14.13.1), alone or coupled to other enzymes, i.e., glucose oxidase (EC 1.1.3.4) or tyrosinase (EC 1.14.18.1) have been proposed (Frew et al., 1989; Oliveira-Neto et al., 1999; Campanella et al., 2006; Cui et al., 2008). In these systems, the analytical signal is obtained by electron transfer during the oxireduction of cathecolic product, which results from the hydroxylation and descarboxylation of salicylate (Oliveira-Neto et al., 1999).

Quantification of salicylate in the range of $7.2510^{-6}$ mol L-1 to $4.35 \times 10^{-3} \mathrm{molL}^{-1}$ was possible with the use of Salicylate hydroxylase (SH) biosensor. The biosensor was constructed by the direct immobilization of SH enzyme on platinum electrodes with the use of glutaraldehyde cross linker and polypyrrole conductive films containing hexacyanoferrate electron mediator. Flow injection analysis systems were employed in this work in order to improve the quality and number of measurements (Milagres, 1997; Neumayr el al, 1995. Carbon paste bi-enzymatic biosensors based on the immobilization of $\mathrm{SH}$ and tyrosinase is also widespread. A detection limit of $3.5 \times 10^{-6} \mathrm{~mol} . \mathrm{L}^{-1}$ was obtained for salicylate by using this simple system (Martin, 1999). Indeed, the use of bi or tri enzymatic systems improves sensitivity at lower working potentials (Moore et al., 1995; Scheller, Scheller, 1996; Cosnier et al., 2001; Cui et al., 2008). The type of transducing element, tech- 
nique of immobilization of the recognizing agent, and use of electron mediators can also define the sensitivity, stability and applicability of biosensors (Kubota et al., 1997; Oliveira-Neto, 1999). The use of carbon fibers for SH immobilization was applied in the development of biosensors for in situ analysis. Furthermore, the architecture of this microelectrode defined the level of sensitivity and stability (Carvalho et al., 2000 and 2001).

Moreover, the SH enzyme occlusion in conductive polymeric films (e.g. polypyrrole) is another widespread immobilization technique (Oubina et al., 1997; RoverJunior et al., 2000).

The immobilization of SH by covalent bond with $p$-tetrachloroquinone, resulted in stable linking allowing the reuse of the enzymatic system for more than one year (Neumayr et al; 1995; Oliveira-Neto et al., 1999).

Recently, a biosensor based on superoxide dismutase enzyme was developed to evaluate the antioxidant and radical scavenger activity of phenolic compounds in aerated medium. This study included the salicylate derivatives, and the principle of detection was based on the dismutation of superoxide into oxygen and hydrogen peroxide (Emregul 2005).

\section{Acetaminophen}

In the presence of hydrogen peroxide, the Horseradish peroxidase (HRP) [EC 1.11.1.7] catalyzes the oxidation of paracetamol (acetaminophen) into $\mathrm{N}$-acetyl- $p$ benzoquinoneimine. Hence, the amperometric biosensors based on direct enzyme immobilization on the transducer surface are the main analytical strategies used for paracetamol analysis (Messina, De-Vito, Raba, 2006).

Among the innumerous procedures carried out toward performance optimization of such devices is that based on nanotechnology. Enzyme immobilization in carbon nanotubes, nanoporous enriched particles, always results in improvement of the transducer surface area and consequent gain in sensitivity (Zhai et al., 2006; Sima et al.,2008).

In this context, the HRP was immobilized in nanoporous magnetized microparticles of silica for the construction of carbon paste biosensors with enhanced performance. The use of such magnetized microparticles allows better fixing of the enzyme to the carbon paste electrode, resulting in improved stability. Furthermore, the increased surface area allowed the quantification of paracetamol at micromolar levels, while the enzyme occlusion in the nanoporous particles reduced its susceptibility to interference from tiols (Yu et al., 2006).

The development of HRP biosensors for paracetamol detection in miniaturized systems for online monito- ring has also been proposed. Such devices make possible paracetamol assays in pharmaceutical formulations in a linear range from 0.35 to $100 \times 10^{-6} \mathrm{~mol} . \mathrm{L}^{-1}$. This system presented a high level of precision and accuracy and a detection limit of $3 \times 10^{-7} \mathrm{molL}^{-1}$ (Messina, De-Vito, Raba, 2006).

Conductive materials often contributes to the analytical signal and warrant recognition in the development of biosensors (Hoshi et al., 2000). Boopathi et al (2004) developed a paracetamol biosensor which had its glassy carbon transducer modified with conductive polymer and cooper (II) complex. The use of this polymer prevents the surface block caused by samples and increased the sensitivity of the sensor. Furthermore, additional pre-treatment steps were avoided.

The modification of transducers with natural enzymes obtained from vegetals is a practical, very interesting option, especially in Brazil. The peroxidases can be found in natural sources, including zucchini and avocado, presenting the great advantage of low cost. Moreover, the use of vegetal tissues provides higher enzymatic stability, since the enzymes are found in the natural environment (Fatibello-Filho et al., 2001; Vieira et al., 2003).

Another interesting model constitutes the use of tyrosinase as a recognizing agent (Wang, Naser, Wollenberger, 1993). The use of this enzyme in the presence of 3-methyl-2-benzothiazolone hydrazone, a powerful nucleophilic agent, enables quantitative analysis of paracetamol in a wide range of concentrations (Valero et al., 2003).

Among the strategies of immobilization most employed in tyrosinase, is occlusion in conductive polymeric membranes (Kim, Lee, 2003). Other strategies suggest the use of screen printed electrodes (Wang et al., 2007).

Laccase is another phenoloxidase used as a recognizing agent in the development of paracetamol biosensors. The co-immobilization of this enzyme with 1-hydroxybenzotriazole, an electron mediator, has resulted in a highly sensitive biosensor with detection limits of submicromolar levels (Odaci et al., 2006). Besides oxidases, the hydrolase, aril-acilamidase, responsible for the conversion of acetaminophen into 4-aminophenol, have also been evaluated in paracetamol analysis. The resulting biochemical product of the reaction was detected at +250 $\mathrm{mV}$ by amperometric biosensor, and the concentration of paracetamol was indirectly quantified (Vaughan, 1991).

\section{NEUROTRANSMITTERS DRUGS}

The electrochemical methods are especially useful in the study of neurotransmitters (NT) and neuronal drugs, not only from a quality control point of view, but 
also for physiological purposes. Voltammetry coupled to microelectrodes modified with drug or NT receptors are a useful tool for evaluating the physiopathological process, elucidating their pharmacological mechanism of action, as well as for the development of new drugs (Crespi, 1995; Urban, 2001; Crespi, 2002).

\section{Catecholamine}

Catecholamines exert many functions at both the central and autonomous nervous systems (Silva, Menezes, Kempinas, 2007). These molecules have an oxidized cathecolic group which can be catalyzed by many oxidases.

The use of vegetal tissues as a source of oxidases for biosensor purposes represents a very promising alternative for the quantification of this class of molecules (Gil et al., 2008; Fatibelo-Filho et al., 2001; Vieira et al., 2003).

The enzyme polyphenoloxidase, present in coconut fiber tissues (Lima et al., 1997), apple (Cummings et al., 1998), avocado (Fatibello-Filho et al.,2001), zucchini (Lupetti et al., 2005), potato (Vieira, Fatibello-Filho et al., 2000), and many kinds of palms (Gil et al., 2008; Felix et al., 2006) have been used as source of enzymes for biosensor development focusing on the analysis of molecules containing cathecolic and phenolic groupings. The polyphenoloxidases catalyze the hydroxylation of phenols to cathecoles, acting as a cathecolase, and in the oxidation of the resulting cathecoles to the respective quinones, exerting their oxidase activity. Due their high selectivity and activity, as well the capacity to act as a direct electron receptor, these enzymes have great analytical potential (Toralles et al., 2004; Fatibello-Filho, Vieira, 2002).

Biosensors containing palm fruit (Livistona chinensis) have been used for the analysis of epinephrine in pharmaceutical formulations at the concentration range of 0.05 to $0.35 \mathrm{mM}$. In comparison to official methods (USP XXX), the results presented great accuracy (3.1\%) and repeatability (Felix, Yamashita, Angnes, 2006). Other palm tissue-based biosensors for catecholamine analysis include the coconut (cocconuts) biosensor (Lima et al., 1997) and the guariroba (Syagrus oleracea) biosensor (Gil et al., 2008).

A biosensor comprising $25 \%(\mathrm{p} / \mathrm{p})$ polyphenoloxidase obtained from banana tissues (Annona muricata L.), $30 \%(\mathrm{p} / \mathrm{p})$ graphite, $30 \%(\mathrm{p} / \mathrm{p})$ silicone oil, and $15 \%(\mathrm{p} / \mathrm{p})$ of $7,7,8,8$ tetracyanoquinodimethane (TCNQ) coupled to flow injection systems (FIA) was successfully used for the determination of dopamine in pharmaceutical formulations. Amperometric detection was performed at 100 $\mathrm{mV}$ (vs Ag/AgCl), $\mathrm{pH} 7.8$ and a $2.5 \mathrm{~mL} / \mathrm{min}$ flow rate. A linear curve from 0.1 to $20 \mathrm{mmolL}^{-1}$ was obtained for both experimental $(\mathrm{RSD}=1.5 \%)$ and real $(\mathrm{RSD}=3.4 \%)$ samples (Bezerra et al., 2003).

Another economical source of enzymes includes the use of microbial cultures, e.g.: crude extracts of laccase from various fungi (Gil et al., 2009; Freire et al., 2001). Recovery rates of between 97.3 and $101 \%$ for adrenaline, and between 95.8 and $102 \%$ for dopamine, as well as good correlation from 0.05 to $0.5 \mathrm{mmolL}^{-1}$ was obtained for carbon paste biosensors prepared with crude extract of laccase (Pleurotus ostreatus). Moreover, a confidence level of $95 \%$ was obtained for analysis of pharmaceuticals produced with this biosensor, comparable to the official method (Leite, Fatibello-Filho, Barbosa, 2003).

Another strategy used in the development of biosensors for dopamine analysis is the employment of biomimetic receptors in planar bi-layers of lipidic membranes. The interaction of dopamine with the NT-receptor produces a transient current signal, which is proportional to the concentration of the NT or drug analogues (Nikolelis, 2002).

\section{Methylxanthines}

Methylxanthines, caffeine, theobromine and teophilin act as stimulants of the central nervous systems and also as muscle relaxants, being commonly indicated in the treatment of asthma (Goodman, Gilman, 1996). Moreover, these compounds can be found in many popular beverages, e.g. coffee and teas. The high consumption of these compounds justifies the development of new analytical methods.

The majority of scientific studies involving biosensors for the analysis of methylxanthines are aimed at the quantification of teophilin. Studies using DNA biosensors and other nucleic acids derivatives have been highlighted (Ferapontova, Olsen, Gothelf, 2008; Rankin, 2006; Sekella, Rueda, Walter, 2002; Buch, Rechnitz, 1989). Aptamers of RNA were co-immobilized with ferrocene (electron mediator) on gold electrodes. This RNA-based biosensor was evaluated for teophilin analysis, by means of cyclic and differential pulse voltammetry, presenting a linear response from 0.2 to $1.0 \mu \mathrm{mol} . \mathrm{L}^{-1}$. The conformational disturbance provoked in the RNA polymer by the bronchodilator results in an increase in mediator-electrode electron transfer, and as a consequence, in the sensitivity of the biosensor. The RNA-biosensor also presented high selectivity, even in the presence of interfering compounds, such as caffeine and theobromine. Moreover, the pretreatment of serum samples with use of RNAase inhibitors enables use of this biosensor for clinical analysis (Ferapontova, Olsen, Gothelf, 2008).

A xanthine oxidase-based biosensor was proposed for the amperometric analysis of teophilin and other xanthenes 
in biological samples. The detection limit of $2 \times 10^{-7}$ molL ${ }^{1}$ was obtained for this device, which was stable for more than three months of conditioning. The selectivity of the xanthine oxidase biosensor was found to be dependent on $\mathrm{pH}$, being optimum for xanthine determination at $\mathrm{pH} 5.5$, while for teophilin, the best response was found between the $\mathrm{pH}$ range of 6.5 and 8.5. Moreover, no interference in the analytical signal was observed for samples containing caffeine or theobromine (Stredansky et al., 2000).

Teophilin oxidase, isolated from microorganisms, is another enzyme that has been explored in the development of sensitive and selective biosensors applied to teophilin analysis (McNeil, Cooper, Spoors, 1992; Christenson, 2004; Ferapontova, Shipovskov, Gorton, 2007). Since this enzyme is almost inactive for caffeine and theobromine at concentrations levels below $100 \mathrm{mgL}^{-1}$, and 3-methylxhantine (below $50 \mathrm{mgL}^{-1}$ ) the selectivity of this enzyme is excellent (McNeil, Cooper, Spoors, 1992).

Considering that xanthines inhibit phosphodiesterase, biosensors based on such enzymes were also proposed (Pizzariello et al., 1999). A phosphodiesterase-based biosensor was developed for caffeine analysis in food and biological samples, offering a detection limit of $0.6 \mathrm{mg} / \mathrm{L}$ and linear response from 0.2 to $4 \mathrm{mg} / \mathrm{mL}$.

Examples of the use of entire cells for the development of xanthine biosensors can also be found in the literature. Pseudomonas alcaligenes (MTCC 5264), immobilized on electrochemical transducers, resulted in a biosensor for caffeine analysis. The principle of analysis is based on the capacity of such microbial cells to consume xanthines. The microbial biosensor presented a response time of three minutes at the concentration range 0.1 to $1 \mathrm{mg} / \mathrm{mL}$. This practical method also showed good selectivity for real samples in comparative studies with high performance chromatography (HPLC) (Babu, 2007). The isolation of specific enzymes from microorganisms of this species has been carried out by many researchers (Mohapatra et al., 2006).

\section{Benzodiazepines}

Benzodiazepines are central inhibitors, commonly used for anxiety treatment. Since the therapeutical success of this class of drugs hinges on the maintenance of strict serum levels, many fatal accidents can occur due to the consumption of benzodiazepines. Hence, the development of methods for benzodiazepines analysis has great importance in many fields, e.g. quality control, clinical analysis and forensic investigations.

Studies describing the electrochemical behavior of temazepam, oxazepam and diazepam on carbon pas- te electrodes were investigated by means of cyclic and pulse differential voltammetry. The optimum conditions of response as well as the influence of interfering agents in clinical and pharmaceutical samples were evaluated. The optimum $\mathrm{pH}$ for temazepam and oxazepam was determined in the range 3.0 to 5.0. However, diazepam responded better in neutral to alkaline $\mathrm{pH}(7.0-10.5)$. The use of bentonite, an adsorbing agent ( $5 \%$ of carbon paste composition), resulted in the improvement of current levels. This fact can be associated to the pre concentration effect. However, these simple systems have not conferred suitable selectivity, a characteristic that can be achieved by the use of biological recognizing agents (Lozano-Chaves et al., 2006).

\section{Neuroleptics and Antidepressants}

Neuroleptics or antipsychotics as well as antidepressants are drugs used in the treatment of psychiatric disorders. Among the main chemical class of antipsychotics are the heterocyclic compounds, such as thioxanthenes and phenothiazines, while the main antidepressants include MAO (Monoamine oxidase) inhibitors and the tricyclic compounds (Goodman, Gilman, 1996).

The phenothiazinic derivatives were analyzed by Petit et al (1999), who developed a highly sensitive method $\left(\mathrm{LOD}=10^{-8} \mathrm{~mol} . \mathrm{L}^{-1}\right)$ based on the use of Horseradish peroxidase and carbon electrodes coupled to FIA systems.

Many transducers have been proposed for neuroleptic detection which, despite presenting low redox activity, can be quantified by amperometric or potentiometric techniques. Hence, haloperidol presents an irreversible anodic peak (Epa $\sim 0.86 \mathrm{~V}$ ) determined with glassy carbon electrodes modified with carbon nanotubes (Huang et al., 2008). The ion-selective electrodes for chlorpromazine were prepared with chlorpromazine-tetraphenylborate complexes incorporated into matrices of PVC. This device was used in FIA systems, presenting a nerstian response from $1.0 \times 10^{-5}$ to $1.0 \times 10^{-2}$ mol.L-1 (Sales, Tomas, Lavandeira, 2006). In other similar proposals, chlorpromazine was indirectly detected by ion selective electrodes of $\mathrm{Pb}^{2+}$. In this case, the drug was oxidized in an oxidative column fitted to an FIA system, where $\mathrm{Pb}^{2+}$ ions are delivered during the oxidative process. The delivery of $\mathrm{Pb}^{2+}$ was proportional to the chlorpromazine concentration, allowing the indirect potentiometric detection of this analyte (Kojio, 1997). In both cases, the oxidase enzymes can be useful in oxidative systems.

Another HRP biosensor, constructed using enzyme immobilization in porous microparticles of silica magnetically linked to a glassy carbon electrode, was evaluated 
for the amperometric analysis of clozapine. The analytical signal is generated during clozapine oxidation in the presence of hydrogen peroxide. Some interfering agents containing thiolic groups were also indirectly determined by means of signal inhibition (Blankert et al., 2004). The same technique of immobilization was used for HRP in carbon paste electrodes, which resulted in a device with higher enzymatic stability, equal sensitivity $(\mathrm{LOD}=0.3$ $\mu \mathrm{mol} / \mathrm{L}$ ), but higher response time (Yu et al., 2006). In this case, the diffusion process of products is a limiting factor to obtaining lower response time (Yu, Blankert, Kauffmann, 2007).

The most commonly used biosensor for MAO inhibitor analysis is based on monoamine oxidases (MAO) connected to amperometric transducers. The analysis of desipramine, pirlindole and fluoxitine was carried out using MAO biosensors, where the enzyme was immobilized in screen printed platinum electrodes. The device presented high sensitivity, and the detection limits were $8.0 \times 10^{-9}, 8.0 \times 10^{-7}$ and $8.0 \times 10^{-10} \mathrm{molL}^{-1}$ for esipramine, pirlindole and fluoxetine, respectively (Medyantseva et al., 2008). Hydrogen peroxide was detected in FIA systems containing immobilized $\mathrm{MAO}$ at $0.7 \mathrm{~V}$. The amperometric sensor was a platinum electrode modified with polypyrrole films, which improves the selectivity of the analytical signal. In this case, the hydrogen peroxide production resulted from the activity of MAO on fluoxetine (Vela et al., 2003). Indeed, many HRP-based biosensors are grounded in the indirect detection of the analyte of interest.

The use of ion-selective electrodes was also applied in the potentiometric determination of the antidepressant nefazodone, a serotonin reuptake inhibitor (Erdem et al., 2000).

\section{Cytotoxics agents}

Many important physiological process and biochemical cycles are based on redox chemical reactions, which involve multiple enzymatic steps. Hence, the electrochemical methods are valuable tools for the quantification and qualitative analysis, and for the obtention of relevant information on mechanism of action, and for the development of new chemotherapeutic agents (La-Scalea et al, 2001; La-Scalea et al, 2002; Goulart, 2006).

However, the inherent complexity of biological systems can allow innumerous interactions between chemical species and the respective molecular target of action, so the rational use of biosensors and electrochemical techniques can be very useful in understanding these processes. Among the main correlations of electrochemical data and biological properties are the following associations: a) electrochemical signal suppression or enhancement for the generation of toxic molecules or for specific biochemical reactions; b) current peaks for the number of electrons involved in the endobiotic redox process; c) potentials shift in the drug binding on a molecular target of action (Brett, Serrano, 1995; Brett et al., 1999a; Gil, Kubota, 2000; Gil et al., 2000; De-Abreu, Ferraz, Goulart, 2002).

Among the main molecular targets of cytotoxic agents are the nucleic acids and functional enzymes of the parasite.

\section{Beta-lactam antibiotics}

The beta lactamases are hydrolytic enzymes produced by many bacteria, conferring to these microorganisms resistance to bet-lactam antibiotics such as penicillins, cephalosporins, cephamycins and carbapenems. The most-investigated biosensor is the device developed for penicilline analysis (Keusgen, 2002). The first biosensors for penicilline were based on penicilinase enzyme, a specific type of beta-lactamase. Beta-lactam ring hydrolysis generates penicilloic acid, which is detected by a potentiometric sensor (Fernandes, 1999). Hence, the use of penicilinase connected to $\mathrm{pH}$ electrodes, is a very simple and classic alternative to $\beta$-lactamic compounds (Park et al, 2004; Papariello et al, 1973). Other procedures for $\beta$-lactamic analysis involve the use of optical biosensors (Cacciatore et al., 2004) and biosensors based on surface plasma resonance (SPR) (Gustavsson, Sternesjö, 2004). The ion-selective sensors for ampicillin and analogs are generally based on ionic exchange membranes. Shvedene and Borovskaya (2003) have described the use of membranes produced by three different ionophores systems containing azo compounds and metallophthalocyanines, while Kulapina et al (2006) proposed the use of membranes of tetradecylammonium (TDA).

In an innovative proposal, Caras and Janata (1980) described the construction of a field-effect transistor (FET) sensitive to $\mathrm{pH}$, modified with pelicilinase. This technology was developed in later research by Liu et al (1998), who proposed the concept of the ion-sensitive field-effect transistor (ISFET). The proposed ISFET responded linearly ( $\mathrm{r}$ $=0.9944$ ) from 0.5 to $8 \mathrm{mmolL}^{-1}$. The great importance of ISFET can be attributed to its capacity to be miniaturized and employed in portables devices (Stradiotto et al., 2003; Fernandes et al., 2001).

An amperometric biosensor developed by the immobilization of tyrosinase in rotary disc electrodes was evaluated for the indirect detection of penicillin. This system was based on the inhibition of current cathodic peaks. The enzymes oxidize cathecol to quinone, which 
is electrochemically reduced at $-150 \mathrm{mV}$. Penicillin was added to the same electrolytic cell which reacts with the $o$-quinone producing theoquinone, consequently decreasing the analytical signal. The decrease in current is proportional to the penicillin concentration, and results in a wide linear curve from 0.02 to $80 \mu \mathrm{M}(\mathrm{r}=0.9990)$. The reproducibility of this indirect system was good (CV $<4.0 \%$ ), and the stability was higher than one month (Torriero et al., 2006).

\section{Antineoplastics}

Neoplasias are diseases in which the growth of the cells, unable to work normally, exceeds that of healthy tissues, suppressing the organic reserves surrounding normal tissues. The main target of antineoplastic agents is nucleic acids. The interaction between DNA or RNA and antineoplastic drug can be electrochemically monitored (Brett, Serrano, 1995; Brett, Piedade, Serrano, 2000). In such studies, the suppression of anodic peaks corresponding to the oxidation of purines and pyrimidines of nucleic acids are commonly observed before and after drug interaction (Gil et al., 2000). The magnitude of the alterations in the analytical signal (e.g. anodic peak suppression of adenine) can be associated to the drug concentration. Hence, nucleic acid modified electrodes have many applications in pharmaceutical analysis including quality control, physiology and medicinal chemistry (Rauf et al., 2005; Erdem, Ozsoz, 2002; Hason et al., 2002; Asphahani, Zhang, 2007). Furthermore, such biopolymers often improve the many properties of the electrode, including the electron transfer rate and conductivity, both decreasing the current capacity and peak potentials (Brett, Serrano, 1995; Gil, Kubota, 2000).

\section{Imidazolic compounds}

The drugs presenting imidazolic rings are often cytotoxic, being employed in the treatment of mycoses, and other parasitic or bacterial infections (Goodman, Gilman, 1996). The mechanism of action involves a redox process that results in the production of free radicals. The nitroimidazoles, for example, are activated by reduction in hypoxic cells followed by a redox cycle that produces toxic compounds (Brett et al., 1997a, Brett et al., 1999b).

DNA sensors have been successfully used to study this class of compound (Brett et al., 1997b). The electrochemical behavior of imidazolic compounds have been studied by DNA modified electrodes, not only for analytical purposes, but also in order to elucidate the mechanism, as well as the level of toxicity (Brett et al, 1996; Brett et al., 1997ª ; La-Scalea, 2002; Zhang et al., 2005).
However, many studies have described DNA modified sensors as conventional biosensors, but given the lack of selectivity of this recognizing agent the use of this term is controversial.

\section{Antraciclins and sulphonamides}

Associations of DNA and enzymes have been proposed for chemotherapeutic agents. This association results in signal amplification, either for conductive improvement of the transducer properties, or for pre-concentration of analyte on the electrode surface. The determination of antracyclins and sulphonamides with glassy carbon $d s$-DNA and HRP modified electrodes was evaluated for these drugs in the oxidation of methylene blue (electron mediator). The detection limits observed for the DNA-HRP-biosensor were $0.002 \mathrm{nmolL}^{-1}$ for sulphamethoxazole, $0.1 \mathrm{nmolL}^{-1}$ for sulphadiazine, $0.01 \mathrm{nM}$ for sulfamethazine, $0.1 \mathrm{nmolL}^{-1}$ for sulphaguanidine, $0.05 \mu \mathrm{molL}^{-1}$ for rubomycine, and of $0.08 \mu \mathrm{molL}^{-1}$ for doxorubicin (Evtugyn et al. , 2005).

\section{Tetracyclines and quinolones}

In the case of antiparasitic drugs, the use of microbial cells as recognizing agents is a promising strategy. In such devices, the influence of the drug on microbial metabolism and proliferation can be used as the principle of the analytical signal.

Traces of quinolones and tetracyclines were detected in milk samples by using a biosensor. The principle of detection was based on the potentiometric determination of carbon dioxide produced by microbial activity of Escherichia coli (ATCC 11303) microbial cultures, and detection limits above $25 \mu \mathrm{gL}^{-1}$ were found. (Pellegrini, Carpico, Coni, 2004).

The indirect determination of tetracyclines based on the potentiometric detection of ammonium (Simpson, Kobos, 1984) or using selective modified PVC membranes for tetracycline have also been described (El-Ansary et $a l, 1999)$. The selectivity of these devices for drugs was evaluated in the presence of many ions, carbohydrates and aminoacids present in biological fluids and pharmaceutical preparations (El-Ansary et al, 1999).

Furthermore, the modification of polymeric membranes with tetracycline has also been evaluated for calcium analysis, in the presence of mono and divalent cations (Baek, Rhee, Paeng, 2006).

A quantitative assay for ciprofloxacin, a quinolinocarboxylic acid derivative, was proposed based on HRP-biosensors. The principle of detection was based on electrochemical reduction of quinones enzimatically 
formed on the electrode surface, which was blocked by piperazine groups of ciprofloxacin (Michael addition mechanism). Hence, in this indirect method, the current suppression was proportional to the ciprofloxacin amount. A linear curve was obtained for the concentration range 0.02 to $65 \mu \mathrm{mol} . \mathrm{L}^{-1}(\mathrm{r}=0.999)$ with a detection limit of $0.4 \mathrm{nmol} . \mathrm{L}^{-1}$, where the optimal experimental condition was observed in neutral $\mathrm{pH}$ (Torriero, 2006 ${ }^{\mathrm{b}}$ ).

\section{CONCLUSION}

The real-time detection of substances is a tendency in analytical chemistry that can be achieved by the use of sensors. The development of biosensors is a promising tool that meets the requirements of low cost, simplicity of analysis, selectivity and good sensitivity.

This review briefly described some of the main applications of these devices for pharmaceutical analysis. In spite of the difficulties concerning the reproducibility of the electrochemical methods and stability of enzymes and other biological recognizing agents, the biosensor remains a focus of research. Hence, many studies on the development of new material transducers, as well as techniques of immobilization of the recognizing agents can be found on literature. However, the consolidation of these devices for use in pharmaceutical analysis, and the introduction of official methods, requires further research.

\section{ACKNOWLEDGEMENTS}

The authors would like to thank Fapeg for the assistance given and Professor Lauro Tatsuo Kubota from the Institute of Chemistry, Unicamp, for the invaluable suggestions and guidance provided.

\section{REFERENCES}

ABREU, F.C.; FERRAZ, P.A.L.; GOULART, M.O.F. Some applications of electrochemistry in biomedical chemistry. Emphasis on the correlation of electrochemical and bioactive properties. J. Braz. Chem. Soc., v.13, n.1, p.1935, 2002.

ASPHAHANI, F.; ZHANG, M. Cellular impedance biosensors for drug screening and toxin detection. Analyst, v.132, n.9, p.835-841, 2007.

BABU, V.R.S.; PATRA, S.; KARANTH, N.G.; KUMAR, M.A.; THAKUR, M.S. Development of a biosensor for caffeine. Anal. Chim. Acta, v.582, n.2, p.329-334, 2007.
BAEK, J.; RHEE, I.; PAENG, K.J. The potentiometric performances of membrane electrodes based on tetracycline antibiotics. J. Kor. Electrochem. Soc., v.9, n.3, p.132-134, 2006.

BALDINI, E.; DALL'ORTO, V. C.; DANILOWICZ, C.; REZZANO, I.; CALVO, E.J. Amperometric detection of peroxides using peroxidase and porphyrin biomimetic modified electrodes. Electroanal., v.14, n.7, p.1157-1164, 2002.

BARDEletti, G.; SECHAUd, F.; COUlET, P.R. Amperometric enzyme electrodes for substrate and enzyme activity determinations. Bioprocess Technol., v.15, n.1, p.7-45, 1991.

BAUER, C.G.; KUHN, A.; GAJOVIC, N.; SKOROBOGATKO, O.; HOLT, P.J.; BRUCE, N.C.; MAKOWER, A.; LOWE, C.R.; SCHELLER, F.W. New enzyme sensors for morphine dehydrogenase and laccase. Fresenius J. Anal. Chem., v.364, n.1-2, p.179-183, 1999.

BEZERRA, V.S.; DE-LIMA-FILHO, J.L.; MONTENEGRO, M.C.B.S.M.; ARAUJO, A.N.; DA-SILVA V.L. Flowinjection amperometric determination of dopamine in pharmaceuticals using a polyphenol oxidase biosensor obtained from soursop pulp. J. Pharm. Biomed. Anal., v.33, n.5, p.1025-31, 2003.

BLANKERT, B.; DOMINGUEZ, O.; EL-AYYAS, W.; ARCOS, J.; KAUFFMANN, J.-M. Horseradish peroxidase electrode for the analysis of clozapine. Anal. Letters, v.34, n.5, p.903913, 2004.

BLUM, L.J., COULET, P.R. Biosensor principles and applications. New York: CRC Press, 1991. 345 p.

BOOPATHI, M.; WON, M.S.; SHIM, Y-B. A sensor for acetaminophen in a blood medium using a $\mathrm{Cu}(\mathrm{II})$ conducting polymer complex modified electrode. Anal. Chim. Acta, v.512, n.2, p.191-197, 2004.

BRETT, A.M.O.; SERRANO, S. H. P. The electrochemical oxidation of DNA. J. Braz. Chem. Soc., v.6, n.1, p.97-100, 1995.

BRETT, A.M.O.; SERRANO, S.H.P.; MACEDO, T.A.; RAIMUNDO, D.; MARQUES, M.H.; LA-SCALEA, M.A. Electrochemical determination of carboplatin in serum using a DNA-modified glassy carbon electrode. Eletroanal., v.8, n.11, p.992-995, 1996. 
BRETT, A.M.O.; SERRANO, S.H.P.; GUTZ, I.; LASCALEA, M.A.; CRUZ, M.L. Voltammetric behavior of nitroimidazoles at a DNA- biosensor. Electroanal., v.9, n.14, p.132-1137, 1997a.

BRETT, A.M.O; SERRANO, S.H.P.; GUTZ, I.; LA-SCALEA, M.A. Electrochemical reduction of metronidazole at a DNA-modified glassy carbon electrode. Bioelectrochem. Bioener., v.42, n.2, p.175-178, 1997 b.

BRETT, A.M.O.; MACEDO, T.R.A.; RAIMUNDO, D.; MARQUES, M.H.; SERRANO, S.H.P. Electrochemical oxidation of mitoxantrone at a glassy carbon electrode. Anal. Chim. Acta, v.385, n.1-3, p.401-408, 1999a.

BRETT, A.M.O.; SERRANO, S.H.P.; LA-SCALEA, M.A.; GUTZ, I.G.R.; CRUZ, M.L. Mechanism of interaction of in situ produced nitroimidazole reduction derivatives with DNA using electrochemical DNA biosensor. Meth. Enzymol., v.B300, p.314-321, 1999b.

BRETT, A.M.O.; PIEDADE, J.A.P.; SERRANO, S.H.P. Electrochemical oxidation of 8-oxoguanine. Electroanal., v.12, n.12, p.969-973, 2000.

BUCH, R. M.; RECHNITZ, G. A. Intact chemoreceptor-based biosensors: responses and analytical limits. Biosensors, v.4, n.4, p.215-30, 1989.

CACCIATORE, G.; PETZ, M.; RACHID, S.; HAKENBECK, R.; BERGWERFF, A.A. Development of an optical biosensor assay for detection of $\beta$-lactam antibiotics in milk using the penicillin-binding protein 2x. Anal. Chim. Acta, v.520, n.1-2, p.105-115, 2004.

CAMPANELlA, L.; GREGORI, E.; TOMASSETTI, M. Salicylic acid determination in cow urine and drugs using a bienzymatic sensor. J. Pharm. Biomed. Anal., v.42, n.1, p.94-99, 2006.

CAMPANELLA, L.; ROVERSI, R.; SAMMARTINO, M. P.; TOMASSETTI, M. Hydrogen peroxide determination in pharmaceutical formulations and cosmetics using a new catalase biosensor. J. Pharm. Biomed. Anal., v.18, n.1-2, p.105-116, 1998.

CARAS, S., JANATA, J. Field effect transistor sensitive to penicillin. Anal. Chem., v.52, n.12, p.1935-1937, 1980.
CARVALHO, R.M.; OLIVEIRA-NETO, G.; KUBOTA, L.T. Influence of different carbon fibers on salicylate microbiosensor performance. Electroanal., v.13, n.2, p.131$136,2001$.

CARVALHO, R.M.; OLIVEIRA-NETO, G.; KUBOTA, L. T. Microbiosensor for salicylate based on modified carbon fiber. Anal. Lett., v.33, n.3, p.425-442, 2000.

CHAILAPAKUL, O.; NGAMUKOT, P.; YOOSAMRAN, A.; SIANGPROH, W.; WANGFUENGKANAGUL, N. Recent electrochemical and Optical Sensors in flow-based analysis. Sens. Act. B., v.6, p.1383-1410, 2006.

CHRISTENSON, A.; DOCK, E.; GORTON, L.; RUZGAS, T. Direct heterogeneous electron transfer of theophylline oxidase. Biosens. Bioelec., v.20, n.2, p.176-183, 2004.

COSNIER, S.; GONDRAN, C.; WATELET, J.C. A polypyrrolebienzyme electrode (salicylate hydroxylase-polyphenol oxidase) for the interference-free determination of salicylate. Electroanal., v.13, n.11, p.906-910, 2001.

COUTO, C.M.C.M.; MONTENEGRO, C.B.S.M. Detectores potenciométricos para sistemas de análise por injeção em fluxo, evolução e aplicação. Quim. Nova. v.23, n.6, p.774$784,2000$.

CRESPI, F.; ENGLAND, T.; RATTI, E.; TRIST, D.G. Carbon fibre micro-electrodes for concomitant in vivo electrophysiological and voltammetric measurements: no reciprocal influences. Neurosci. Lett., v.188, n.1, p.33-36, 1995.

CRESPI, F. In vivo voltammetry and concomitant electrophysiology at a single micro-biosensor to analyse ischaemia, depression and drug dependence. J. Neurosci. Meth., v.119, n.2, p.173-184, 2002.

CUI, Y.; BARFORD, J.P.; RENNEBERG, R. Amperometric trienzyme ATP biosensors based on the coimmobilization of salicylate hydroxylase, glucose-6-phosphate dehydrogenase, and hexokinase. Sens. Act. B., v.132, n.1, p.1-4, 2008.

CUMMINGS, E.A.; MAILLEY, P.; LINQUETTE-MAILLEY, S.; EGGINS, B.R.; McADAMS, E.T.; McFADDEN, S. Amperometric carbon paste biosensor based on plant tissue for the determination of total flavanol content in beers. Analyst, v.123, n.10, p.1975-1980, 1998. 
DANTONI, P.; SERRANO, S.H.P.; BRETT, A.M.O.; GUTZ, I.G.R. Flow-injection determination of catechol with a new tyrosinase/DNA biosensor. Anal. Chim. Acta, v.366, n.1-3, p.137-145, 1998.

DICKERT, F.L.; FORTH P.; LIEBERZEIT, P.A.; VOIGT, G. Quality control of automotive engine oils with masssensitive chemical sensors-QCMs and molecularly imprinted polymers. Fres. J. Anal. Chem., v.366, n.8, p.802-806, 2000.

DORF, R.C. The electrical engineering handbook: Sensors, nanoscience, biomedical engineering and instruments. New York:CRC, 2006. 392 p.

EL-ANSARY, A.L.; ISSA, Y.M.; TAG-ELDIN, A.S. Tetracycline sensitive membrane electrodes based on poly (vinyl chloride) matrices and their use in drug analysis. Anal. Letters, v.32, n.11, p.2177-2190, 1999.

EL-HADY, D.A.; SELIEM, M.M.; GOTTI, R.; EL-MAALI, N.A. Novel voltammetric method for enantioseparation of racemic methotrexate. Determination of it's enantiomeric purity in some pharmaceuticals. Sensors and Actuators B., v.113, n.2, p.978-988, 2006.

EMREGUL, E. Development of a new biosensor for superoxide radicals. Anal. Bioanal. Chem., v.383, n.6, p.947-954, 2005.

ERDEM, A.; OZKAN, D.; KERMAN, K.; MERIC, B.; DALBASTI, T.; OZSOZ, M. Ion-selective membrane electrode for the determination of a novel phenylpiperazine antidepressant Nefazodone. Turk J. Chem. v.24, n.4, p.353$360,2000$.

ERDEM, A.; OZSOZ, M., Electrochemical DNA biosensors based on DNA-drug interactions. Electroanal., v.14, n.14, p.965-974, 2002.

ERDEM, A.; PABUCCUOGLU, A.; MERIC, B.; KERMAN, K.; OZSOZ, M. Electrochemical biosensor based on horseradish peroxidase for the determination of oxidizable drugs. Turk. J. Med. Sc., v.30, n.4, p.349-354, 2000.

EVTUGYN, G.A.; GOLDFARB, O.E.; BUDNIKOV, H.C.; IVANOV, A.N.; VINTER, V.G. Amperometric DNAperoxidase sensor for the detection of pharmaceutical preparations. Sensors., v.5, n.6-10, p.364-376, 2005.
FATIBELLO-FILHO, O., VIEIRA, I.C. Uso analítico de tecidos e extratos vegetais como fonte enzimática. Quim. Nova, v.25, n.3, p.455-464, 2002.

FATIBELLO-FILHO, O.; LUPETTI, K.O.; VIEIRA, I.C. Chronoamperometric determination of paracetamol using an avocado tissue (Persea americana) biosensor. Talanta, v.55, n.4, p.685-692, 2001.

FATIBELLO-FILHO, O.; LUPETTI, K.O.; LEITE, O.D.; VIEIRA, I.C., Electrochemical biosensors based on vegetable tissues and crude extracts for environmental, food and pharmaceutical analysis, Compr. Anal. Chem., v.49, n.17, p.357-377, 2007.

FELIX, F.S.; BRETT, C.M.A.; AGNES, L. Carbon film resistor electrode for amperometric determination of acetaminophen in pharmaceutical formulations. J. Pharm. Biomed. Anal., v.43, n.5, p.1622-1627, 2007.

FELIX, F.S.; YAMASHITA, M.; ANGNES, L. Epinephrine quantification in pharmaceutical formulations utilizing plant tissue biosensors. Bios. Bioelec., v.21, n.12, p.22832289, 2006.

FERAPONTOVA, E.E.; OLSEN, E.M.; GOTHELF, K.V. An RNA Aptamer-based electrochemical biosensor for detection of theophylline in serum. J. Am. Chem. Soc., v.130, n.13, p.4256-4258, 2008.

FERAPONTOVA, E.E.; SHIPOVSKOV, S.; GORTON, L. Bioelectrocatalytic detection of theophylline at theophylline oxidase electrodes. Bios. Bioelec., v.22, n.11, p.2508-2515, 2007.

FERNANDES, J.C.B.; KUBOTA, L.T. Eletrodos íon-seletivos: histórico, mecanismo de resposta, seletividade e revisão de conceitos. Quim. Nova, v.24, n.1, p.120-130, 2001.

FERNANDES, J.C.B.; KUBOTA, L.T.; NETO, G.O. Eletrodos íon-seletivos: histórico, mecanismo de resposta, seletividade e revisão de conceitos. Quim. Nova, v.24, n.1, p.120-130, 2001.

FERNANDES, J.C.B.; KUBOTA, L.T.; OLIVEIRA-NETO, G. Potentiometric biosensor for I-ascorbic acid based on ascorbate oxidase of natural source immobilized on ethylene-vinylacetate membrane. Anal. Chim. Acta, v.385, n.1-3, p.3-12, 1999. 
FREIRE, R.S.; DÚRAN, N.; KUBOTA, L.T. Effects of fungal laccase immobilization procedures for the development of a biosensor for phenol compounds. Talanta, v.54, n.4, p.681-686, 2001.

FREIRE, R.S.; DURAN, N.; WANG, J.; KUBOTA, L.T. Laccase-based screen printed electrode for amperometric detection of phenolic compounds. Anal. Lett., v.35, n.1, p.29-38, 2002.

FREW, J.E.; BAYLIFF, S.W.; GIBBS, P.N.B.; GREEN, M.J. Amperometric biosensor for the rapid determination of salicylate in whole blood. Anal. Chim. Acta., v.224, n.1, p.39-46, 1989.

FRIEDERKEES, D.J., GROBECKER, H. Simultaneous determination of acetylsalicylic acid and salicylic acid in human plasma by high - performance liquid chromatography, J. Biomed. Sci. Appl., v.677, n.1, p.172$177,1996$.

GIL, E.S.; KUBOTA, L.T., Electrochemical properties of Doyle catalyst immobilized on carbon paste in the presence of DNA. Bioelectrochem. Bioenerg., v.51, n.2, p.145-149, 2000 .

GIL, E.S. Controle fisico-químico de qualidade de medicamentos. 2.ed. São Paulo: Editora Pharmabooks, 2007. 485 p.

GIL, E.S.; MULLER, L.; SANTIAGO, M.F.; GARCIA, T.A., Biosensor based on brut extract from Laccase (Pycnoporus sanguineus) for environmental analysis of phenolic compounds. Port. Electrochim. Acta, v.27, n.3, p.215-225, 2009 .

GIL, E.S.; MORAES, F.C.; OLIVEIRA, A.; SANTANA, J.C.; DE-SIQUEIRA, E.Q.; MACHADO, S.A.S. Development of a modified biosensor by a crude extract of Guariroba (Syagrus oleracea) for the analysis of phenolic compounds in environmental samples. In: SPRING MEETING OF INTERNATIONAL SOCIETY OF ELECTROCHEMISTRY, 6., 2008, Foz do Iguaçu. Book of Abstracts. Lausanne: International Society of Electrochemistry, 2008. p.148.

GIL, E.S.; SERRANO, S.H.P.; FERREIRA, E.I.; KUBOTA, L.T. Electrochemical evaluation of rhodium dimer-DNA interactions. J. Pharm. Biomed. Anal., v. 29, n. 4, p. 579$584,2002$.
GOODMAN \& GILMAN's. The Pharmacological Basis of Therapeutics. 9. ed. New York: Editora Mc Graw Hill, 1996. $1905 \mathrm{p}$.

GOULART, M.O.F.; SANT'ANA, A.E.G.; FONTES, G.; ROCHA, E.M.M. Application of electrochemistry in biomedical sciences. Electrochemistry of antiparasitic drugs. In: SQUELLA, J.A.; S. BOLLO; NÚNEZVERGARA, L.J., (Orgs.). Electroanalytical aspects of biological significance compounds. Kerala: Transworld Research Network, 2006. v.1, p.1-32.

GUSTAVSSON, E., STERNESJÖ, A. Biosensor analysis of $\beta$-lactams in milk: comparison with microbiological, immunological, and receptor-based screening methods. $J$. AOAC Int., v.87, n.3, p.614-620, 2004.

HART, J.P.; CREW, A.; CROUCH, E.C; HONEYCHURCH, K.C.; PEMBERTON, R.M.F. Some recent designs and developments of screen-printed carbon electrochemical sensors/biosensors for biomedical, environmental, and industrial analyses. Anal. Lett., v.37, n.5, p.789-830, 2004.

HARWOOD, G.W.J., POUTON, C.W. Amperometric enzyme biosensors for the analysis of drugs and metabolites. Adv. Drug Deliv. Rev., v.18, n.2, p.163-191, 1996.

HASON, S.; DVORAK, J.; JELEN, F.; VETTERL, V. Impedance analysis of DNA and DNA-drug interactions on thin mercury film electrodes. Crit. Rev. Anal. Chem., v.32, n.2, p.167-179, 2002.

HASSAN, S.S. M.; EL-BAZ, A. F.; ABD-RABBOH, H.S.M. A novel potentiometric biosensor for selective L-cysteine determination using L-cysteine-desulfhydrase producing Trichosporon jirovecii yeast cells coupled with sulfide electrode. Anal. Chim. Acta, v.602, n.1, p.108-113, 2007.

HASSAN, S.S.M.; RAGAB, M.A.A.; ABDEL-SAMAD, M.S. Plastic membrane electrode for selective determination of diclofenac (voltaren) in pharmaceutical preparations. The Analyst, v.119, n.9, p.1993-1996, 1994.

HE, P.; XU, Y.; FANG, Y. Applications of carbon nanotubes in electrochemical DNA biosensors. Microchim. Acta, v.152, n.2, p.175-186, 2006. 
HOSHI, T.; SAIKI, H.; KUWAZAWA, S.; KOBAYASHI, Y.; ANZAI, J.I. Polyelectrolyte multilayer film-coated electrodes for amperometric determination of hydrogen peroxide in the presence of ascorbic acid, uric acid and acetaminophen. Anal. Sci., v.16, n.10, p.1009-1010, 2000.

HUANG, F.; PENG, Y.; JIN, G.; ZHANG, S.; KONG, J. Sensitive detection of haloperidol and hydroxyzine at multiwalled carbon nanotubes-modified glassy carbon electrodes. Sensors, v.8, n.3, p.1879-1889, 2008.

JESUS, D.S.; COUTO, C.M.C.M.; ARAUJO, A.N.; MONTENEGRO, M.C.B.S.M. Amperometric biosensor based on monoamine oxidase (MAO) immobilized in solgel film for benzydamine determination in pharmaceuticals. J. Pharm. Biomed. Anal., v.33, n.5, p.983-990, 2003.

KARAKUS, E.; ERDEN, P.E.; PEKYARDIMCI, S.; KILIC, E. Determination of creatine powder with new potentiometric and amperometric biosensors. Artif. Cells, Blood Subst. Biotech., v.34, n.3, p.337-347, 2006.

KATAKY, R.; PARKER, D.; KELLY, P. M. Potentiometric enantioselective sensors for alkyl and aryl ammonium ions of pharmaceutical significance based on lipophilic cyclodextrins. Scand. J. Clin. Lab. Invest., v.55, n.5. p.409419, 1994.

KAUFFMANN, J.M. Biosensors: unique tools in the pharmaceutical era. Arhiv. Farmaciju., v.52, n.3, p.121127,2002

KEUSGEN, M. Biosensors: New approaches in drug discovery. Naturwissen., v.89, n.10, p.433-444, 2002.

KEUSGEN, M.; KLOOCK, J.P.; KNOBBE, D.-T.; JUNGER, M.; KREST, I.; GOLDBACH, M.; KLEIN, W.; SCHONING, M.J. Direct determination of cyanides by potentiometric biosensors. Sens. Act., v.103, n.1-2, p.380-385, 2004.

KIM, M.A.; LEE, W.Y. Amperometric phenol biosensor based on sol-gel silicate/Nafion composite film. Anal. Chim. Acta, v. 479, n.2, p.143-150, 2003.

KINDSCHY, L.M.; ALOCILJA, E.C. Development of a molecularly imprinted biomimetic electrode, Sensors, v.7, n.8, p.1630-1642, 2007.

KOHLI, P.; WIRTZ, M.; MARTIN, C.R. Nanotube membrane based biosensors Electroanal., v.16, n.1-2, p.9-18, 2004.
KOJIO, A. Indirect potentiometric determination of chlorpromazine with an oxidative column in a flow injection system. Anal. Letters, v.30, n.13, p.2353-2363, 1997.

KOKOT, Z., BURDA, K. Simultaneous determination of salicylic acid and acetylsalicylic acid in aspirin delayedrelease tablet formulations by second-derivative UVspectrophotometry. J. Pharm. Biomed. Anal., v.18, n.4-5, p.871-875, 1998.

KOZAN, J.V.B.; SILVA, R.P.; SERRANO, S.H.P.; LIMA, A.W.O.; ANGNES, L. Biosensing hydrogen peroxide utilizing carbon paste electrodes containing peroxidases naturally immobilized on coconut (Cocus nucifera L.) fibers. Anal. Chim. Acta, v.591, n.2, p.200-207, 2007.

KUBOTA, L.T.; KLEINKE, M.U.; MELLO, C.; BUENO, M.I.; OLIVEIRA-NETO, G. Experimental evidence of the chaotic regime in a salicylate biosensor. Chem. Phys. Lett., v.264, n.6, p.662-666, 1997.

KULAPINA, E.G.; BARAGUZINA, V.V.; KULAPINA, O.I. Íon-selective sensors for determining ampicillin and oxacillin in biological fluids and pharmaceuticals. Pharm. Chem. J., v.40, n.3, p.171-174, 2006.

LA-SCALEA, M.A.; MAN-CHIN, C.; CRUZ, M.L.; SERRANO, S.H.P.; FERREIRA, E.I. Dissociation and electrooxidation of primaquine diphosphate as an approach to the study of anti-chagas prodrugs mechanism of action. Bioelectrochem.,v.53, n.1, p.55-59, 2001.

LA-SCALEA, M.A; SERRANO, S.H.P; FERREIRA, E.I.; BRETT, A.M.O. Voltammetric behavior of benznidazole at a DNA-electrochemical biosensor. J. Pharm. Biomed. Anal., v.29, n.3, p.561-568, 2002.

LEITE, O.D.; FATIBELLO-FILHO, O.; BARBOSA, A.M. Determination of catecholamines in pharmaceutical formulations using a biosensor modified with a crude extract of fungi laccase (Pleurotus ostreatus). J. Braz. Chem. Soc., v.14, n.2, p.297-303, 2003.

LIMA, A.W.O.; NASCIMENTO, V.B.; PEDROTTI, J.J.; ANGNES, L. Coconut-based plant tissue reactor for biosensing of cathecol in flow injection analysis. Anal. Chim. Acta, v.354, n.1-3, p.325-331, 1997. 
LIMA, R.S.; NUNES, G.S.; NOGUER, T.; MARTY, J.L. Enzymatic biosensor for the detection of dithiocarbamate fungicides. Kinetic study of aldehyde dehydrogenase enzyme and biosensor optimization. Quim. Nova, v.30, n.1, p.9-17, 2007.

LIU, J.; LI, L.; LI, GAOXIANG; H.R.; CHEN, K. H'ISFETbased biosensor for determination of penicillin G. Bios. Bioelec., v.13, n.9, p.1023-1028, 1998.

LOJOU, E., BIANCO, P. Application of the electrochemical concepts and techniques to amperometric biosensor devices. J. Electroceram., v.16, n.1, p.79-91, 2006.

LOWE, C.R. Chemoselective biosensors. Curr. Opin. Chem. Biol., v.3, n.1, p.106-111, 1999.

LOZANO-CHAVES, M.E.; PALACIOS, J.M.S.; CUBILLANA, L.M.A.; NARANJO, I.R.; HIDALGO, J.L.H.C. Modified carbon-paste electrodes as sensors for the determination of 1,4-benzodiazepines: Application to the determination of diazepam and oxazepam in biological fluids. Sens. Act., v.115, n.2, p.575-583, 2006.

MAIER, N.M., LINDNER, W. Chiral recognition applications of molecularly imprinted polymers: a critical review. Anal. Bioanal. Chem., v.389, n.2, p.377-397, 2007.

MALHOTRA, B. D.; CHAUBEY, A.; SINGH, S.P. Prospects of conducting polymers in biosensors. Anal. Chim. Acta, v.578, n.1, p.59-74, 2006.

MARTIN, C., DOMINGUEZ, E. A new enzyme electrode for quantification of salicylic acid in a FIA system. J. Pharm. Biomed. Anal., v.19, n.1-2, p.107-113, 1999.

MCNEIL, C.J.; COOPER J. M.; SPOORS J.A. Amperometric enzyme electrode for determination of theophylline in serum. Biosens. Bioelec., v.7, n.5, p.375-380, 1992.

MED YAN T SEVA, E.P.; VAR LA MOVA, R.M .; GIMALETDINOVA, D.A.; FATTAKHOVA, A.N.; BUDNIKOV, G.K. An amperometric monoamine oxidase biosensor for determining some antidepressants. J. Anal. Chem., v.63, n.3, p.275-279, 2008.

MESSINA, G.A.; DE VITO, I.E.; RABA, J. On-line microfluidic sensor integrated with an enzyme-modified pre-cell for the monitoring of paracetamol in pharmaceutical samples. Anal. Chim. Acta, v.559, n.2, p.152-158, 2006.
MEYERHOFF, M.E.; ROBINS, R. H. Disposable potentiometric ammonia gas sensor for estimation of ammonia in blood. Anal. Chem., v.52, n.14, p.2383-2387, 1980.

MOHAPATRA, B. R.; HARRIS, N.; NORDIN, R.; MAZUMDER, A. Purification and characterization of a novel caffeine oxidase from Alcaligenes species. $J$. Biotech.,v.125, n.3, p.319-327, 2006.

MOJTABA, S.; FAHIMEH, J.; SOHRAB, E. Preparation of a diclofenac potentiometric sensor and its application to pharmaceutical analysis and to drug recovery from biological fluids. J. Pharm. Biomed. Anal., v.37, n.5, p.943947, 2005.

MOORE, T.J.; JOSEPH, M.J.; ALLEN, B.W.; COURY-JR, L.A. Enzymically amplified voltammetric sensor for microliter sample volumes of salicylate. Anal. Chem., v.67, n.11, p.1896-1902, 1995.

MOUSTY, C. Sensors and biosensors based on clay-modified electrodes-new trends. Appl. Clay Sci., v.27, n.3-4, p.159$177,2004$.

NASCIMENTO, V.B.; ANGNES, L. Screen - printed electrodes. Quim.Nova, v.21, n.5, p. 614-629, 1998.

NAKAMURA, H., KARUBE, I. Current research activity in biosensors. Anal. Bioanal. Chem., v.377, n.3, p.446-468, 2003.

NEUMAYR, M.; SONTAG, G.; PITTNER, F. Enzymic sensor coupled to a flow-injection analysis system for the determination of salicylate. Anal. Chim. Acta, v.305, n.1-3, p.26-31, 1995.

NIKOLELIS, D.P.; PETROPOULOU, S.S.E.; PERGEL, E.; TOTH, K. Biosensors for the rapid detection of dopamine using bilayer lipid membranes (BLMs) with incorporated calix[4]resorcinarene receptor. Electroanal., v.14, n.11, p.783-789, 2002.

NORBERT, M.M., WOLFGANG, L. Chiral recognition applications of molecularly imprinted polymers: a critical review. Anal. Bioanal. Chem., v.389, n.2, p.377-397, 2007.

ODACI, D.; TIMUR, S.; PAZARLIOGLU, N.; KIRGOEZ, U.A.; TELEFONCU, A. Effects of mediators on the laccase biosensor response in paracetamol detection. Biotech. Appl. Biochem., v.45, n.1, p.23-28, 2006. 
OEZKAN, S.A.; USLU, B.; ABOUL-ENEIN, H.Y., Analysis of pharmaceuticals and biological fluids using modern electroanalytical techniques. Crit. Rev. Anal. Chem., v.33, n.3, p.155-181, 2003.

OLIVEIRA-NETO, G.; ROVER-JUNIOR, L.; KUBOTA, L.T. Electrochemical biosensors for salicylate and its derivatives. Electroanal., v.11, n.8, p.527-533, 1999.

OUBINA, A.; GASCON, J.; BARCELO, D. A new amperometric biosensor for salicylate based on salicylate hydroxylase immobilized on polypyrrole film doped with hexacyanoferrate. Anal. Chim. Acta, v.347, n.1-2, p.35-41, 1997.

OZOEMENA, K.I.; STEFAN, R.-I.; VAN-STADEN, J.F.; ABOUL-ENEIN, H.Y. Enantioanalysis of S-perindopril using different cyclodextrin-based potentiometric sensors. Sens. Act. B., v.105, n.2, p.425-429, 2005.

PAPARIELLO, G.J.; MUKHERJI, A.K.; SHEARER, C.M. A penicillin selective enzyme electrode. Anal. Chem., v.45, n.4, p.790-792, 1973.

PARK, I.S.; DONG-KYUNG, K.; NANSOO, K., Characterization and food application of a potentiometric biosensor measuring B-Lactam antibiotics. J. Microb. Biotech., v.14, n.4, p.698-706, 2004.

PELLEGRINI, G.E.; CARPICO, G.; CONI, E. Electrochemical sensor for the detection and presumptive identification of quinolone and tetracycline residues in milk. Anal. Chim. Acta, v.520, n.1-2, p.13-18, 2004.

PEREIRA, A.C.; SANTOS, A.S.; KUBOTA, L.T. Tendências em modificação de eletrodos amperométricos para aplicações eletroanalíticas. Quím. Nova, v.25, n.6, p.1012$1021,2002$.

PETIT, C.; MURAKAMI, K.; ERDEM, A.; KILINC, E.; BORONDO, G.O.; LIEGEOIS, J.F.; KAUFFMANN, J.M. Horseradish peroxidase immobilized electrode for phenothiazine analysis. Electroanal., v.10, n.18, p.12411248, 1999.

PIZZARIELLO, A.; SVORC, J.; STRED'ANSKY, M.; MIERTUS, S. A biosensing method for detection of caffeine in coffee. J. Sci. Food Agric., v.79, n.8, p.1136-1140, 1999.
QI, H.; ZHANG, C.; LI, X. Amperometric third-generation hydrogen peroxide biosensor incorporating multiwall carbon nanotubes and hemoglobin. Sens. Act. B., v.114, n.1, p.364-370, 2006.

RADOMSKA, A.; KONCKI, R.; PYRZYNSKA, K.; GLAB, S. Bioanalytical system for control of hemodialysis treatment based on potentiometric biosensors for urea and creatinine. Anal. Chim. Acta, v.523, n.2, p.193-200, 2004.

RANKIN, C.J.; FULLER, E.N.; HAMOR, K.H.; GABARRA, S.A.; SHIELDS, T.P. A simple fluorescent biosensor for theophylline based on its RNA aptamer. Nucleos., Nucleot. Nucleic Acids, v.25, n.12, p.1407-1424, 2006.

RAUF, S.; GOODING, J.J.; AKHTAR, K.; GHAURI, M.A.; RAHMAN, M.; ANWAR, M.A.; KHALID, A.M. Electrochemical approach of anticancer drugs-DNA interaction. J. Pharm. Biomed. Anal., v.37, n.2, p.205-217, 2005.

RAVISHANKARA, M.N.; PILLAI, A.D.; HANDRAL, R.D. Biosensor and its applications. East. Pharm., v.44, n.524, p.21-25, 2001.

ROVER-JUNIOR, L.; OLIVEIRA-NETO, G.; FERNANDES, J.R.; KUBOTA, L.T. Determination of salicylate in blood serum using an amperometric biosensor based on salicylate hydroxylase immobilized in a polypyrrole-glutaraldehyde matrix. Talanta, v.51, n.3, p.547-557, 2000.

RUSLING, J.F.; HVASTKOVS, E.G.; HULL, D.O.; SCHENKMAN, J.B. Biochemical applications of ultrathin films of enzymes, polyions and DNA. Chem. Commun., v.44, n.2, p.141-154, 2008.

SABAH, S.; AGHAMOHAMMADI, M.; ALIZADEH, N. Solid-state valproate íon selective sensor based on conducting polypyrrole films for determination of valproate in pharmaceutical preparations. Sens. Actuators B., v.114, n.1, p.489-496, 2006.

SALES, M.G.F.; TOMAS, J.F.C.; LAVANDEIRA, S.R. Flow injection potentiometric determination of chlorpromazine. J. Pharm. Biomed. Anal., v.41, n.4, p.1280-1286, 2006.

SCHELLER, F.W.; SCHELLER, A.B. Bi-enzyme electrode for measuring sorbitol in pharmaceutical products. GIT Fachzeit. Lab., v.40, n.7, p.706, 708-709, 1996. 
SEKELLA, P.T.; RUEDA, D.; WALTER, N.G. A biosensor for theophylline based on fluorescence detection of ligandinduced hammerhead ribozyme cleavage. $R N A$, v.8, n.10, p.1242-1252, 2002.

SHVEDENE, N.V.; BOROVSKAYA, S. V. Determination of $\beta$-lactam antibiotics by potentiometry with ion-selective electrodes. J. Anal. Chem., v.58, n.11, p.1085-1090, 2003.

SILVA, D.A.F.; MENEZES, M.L.; KEMPINAS, W.G. Desenvolvimento e validação de método analítico para determinação simultânea de catecolaminas em órgãos reprodutores de ratos por cromatografia líquida de alta eficiência com detecção eletroquímica. Ecl. Quím., v.32, n.4, p.35-42, 2007.

SIMA, V.; CRISTEA, C.; LAPADUS, F.; MARIAN, I.O.; MARIAN, A., SANDULESCU, R. Electroanalytical properties of a novel biosensor modified with zirconium alcoxide porous gels for the detection of acetaminophen. $J$. Pharm. Biomed. Anal., v.48, n.4, p.1195-1200, 2008.

SIMPSON, D.L., KOBOS, R.K. Microbiological assay of antibiotics based on inhibition of ammonia production monitored with an ammonia electrode. Anal. Chim. Acta, v.164, n.1, p.273-277, 1984.

STEFAN, R.-I.; VAN-STADEN, J.F.; ABOUL-ENEIN, H.Y. Analysis of chiral drugs with enantioselective biosensors. An overview. Electroanal., v.11, n.16, p.1233-1235,1999.

STRADIOTTO, N.R.; YAMANAKA, H.; ZANONI, M.V.B. Eletrochemical sensors: a power tool in analytical chemistry. J. Braz. Chem. Soc., v.14, n.2, p.159-173, 2003.

STREDANSKY, M.; PIZZARIELLO, A.; MIERTUS, S.; SVORC, J. Selective and sensitive biosensor for theophylline based on xanthine oxidase electrode. Anal. Biochem., v.285, n.2, p.225-229, 2000.

SUPRUN, E.; EVTUGYN, G.; BUDNIKOV, H.; RICCI, F.; MOSCONE, D.; PALLESCHI, G. Acetylcholinesterase sensor based on screen-printed carbon electrode modified with prussian blue. Anal. Bioanal. Chem., v.383, n.4, p.597604, 2005.

TAN, Y.; ZHOU, Z.; WANG, P.; NIE, L.; YAO, S. A study of a bio-mimetic recognition material for the BAW sensor by molecular imprinting and its application for the determination of paracetamol in the human serum and urine. Talanta, v.55, n.2, p.337-347, 2001.
TOMITA, I.N.; MANZOLI, A.; FERTONANI, F.L.; YAMANAKA, H. Amperometric biosensor for ascorbic acid. Ecl. Quim., v.30, n.2, p.37-43, 2005.

TORALLES, S.L.R.; FERRI, N.L.; DEL-PINO, F.A.B.; ANTUNES, P.L., Caracterização parcial do escurecimento enzimático pela polifenoloxidase em pêssegos das cv. Granada, Jade, Esmeralda e Maciel. Rev. Bras. Agroc., v.10, n.1, p.241-244, 2004.

TORRIERO, A.A.J.; RUIZ-DIAZ, J.J.J.; SALINAS, E.; MARCHEVSKY, E.J.; SANZ, M.I.; RABA, J. Enzymatic rotating biosensor for ciprofloxacin determination. Talanta, v.69, n.3, p.691-699, 2006.

TORRIERO, A.A.J.; SALINAS, E.; MARCHEVSKY, E.J.; RABA, J.; SILBER, J.J. Penicillamine determination using a tyrosinase micro-rotating biosensor. Anal. Chim. Acta, v.580, n.2, p.136-142, 2006.

TROJANOWICZ, M. Flow injection analysis: instrumentation and applications. Singapura: World Scientific, 2000. 480 p.

URBAN, G. Biosensor microsystems. Sens. Up., v.8, n.1, p.189214, 2001.

USLU, B.; OZKAN, S.A. Electroanalytical application of carbon based electrodes to the pharmaceuticals. Anal. Lett., v.40, n.5, p.817-853, 2007.

USLU, BENGI; OZKAN, SIBEL A. Solid electrodes in electroanalytical chemistry: present applications and prospects for high throughput screening of drug compounds. Comb. Chem. High Through. Scr., v.10, n.7, p.495-513, 2007

VALERO, E.; CARRION, P.; VARON, R.; GARCIACARMONA, F. Quantification of acetaminophen by oxidation with tyrosinase in the presence of Besthorn's hydrazone. Anal. Biochem., v.318, n.2, p.187-195, 2003.

VAUGHAN, P. A.; SCOTT, L. D. L.; MCALEER, J. F. Amperometric biosensor for the rapid determination of acetaminophen in whole blood. Anal. Chim. Acta., v.248, n.2, p.361-365, 1991.

VELA, M.H.; DE-JESUS, D.S.; COUTO, C.M.M.; ARAUJO, A.N.; MONTENEGRO, M.C.B. S.M. Electroimmobilization of MAO into a polypyrrole film and its utilization for amperometric flow detection of antidepressant drugs. Electroanal., v.15, n.2, p.133-138, 2003. 
VIEIRA, I. C., FATIBELLO-FILHO, O. Biosensor based on paraffin / graphite modified with sweet potato tissue for the determination of hydroquinone in cosmetic cream in organic phase. Talanta, v.52, n.4, p.681-689, 2000.

VIEIRA, I.C.; LUPETTI, K.O.; FATIBELLO-FILHO, O. Determination of paracetamol in pharmaceutical products using a carbon paste biosensor modified with crude extract of zucchini (Cucúrbita pepo). Quim. Nova, v.26, n.1, p.3943, 2003.

WANG, C.; LI, C.; WEI, L.; WANG, C. Electrochemical sensor for acetaminophen based on an imprinted $\mathrm{TiO}_{2}$ film prepared by liquid phase deposition. Microchim. Acta, v.158, n.3-4, p.307-313, 2007.

WANG, J. Amperometric biosensors for clinical and therapeutic drug monitoring: a review. J. Pharm. Biomed. Anal., v.19, n.1-2, p.47-53, 1999.

WANG, J.; NASER, N.; WOLLENBERGER, U. Use of tyrosinase for enzymic elimination of acetaminophen interference in amperometric sensing. Anal. Chim. Acta, v.281, n.1, p.19-24, 1993.

YU, D.; BLANKERT, B.; BODOKI, E.; BOLLO, S.; VIRE, J.C.; SANDULESCU, R.; NOMURA, A.; KAUFFMANN, J.-M. Amperometric biosensor based on horseradish peroxidase-immobilised magnetic microparticles. Sens. Actuators B. v.113, n.2, p.749-754, 2006.
YU, D.; BLANKERT, B.; VIRE, J.-C.; KAUFFMANN, J.-M. Biosensors in drug discovery and drug analysis. Anal. Letters, v.38, n.11, p.1687-1701, 2005.

YU, D.; BLANKERT, B.; KAUFFMANN, J.M. Development of amperometric horseradish peroxidase based biosensors for clozapine and for the screening of thiol compounds, Bios. Bioelec., v.22, n.11, p.2707-2711, 2007.

YU, D.; RENEDO, O.D.; BLANKERT, B.; SIMA, V.; SANDULESCU, R.; ARCOS, J.; KAUFFMANN, J.M. A peroxidase-based biosensor supported by nanoporous magnetic silica microparticles for acetaminophen biotransformation and inhibition studies. Electroanal., v.18, n.17, p.1637-1642, 2006.

ZHAI, X.; WEI, W.; ZENG, J.; LIU, X.; GONG, S. New nanocomposite based on prussian blue nanoparticles/carbon nanotubes/chitosan and its application for assembling of amperometric glucose biosensor. Anal. Lett., v.39, n.5, p.913-926, 2006.

ZHANG, S.S.; NIU, S.; QU, B.; JIE, G.F.; XU, H.; DING, C.F. Studies on the interaction mechanism between hexakis(imidazole) manganese(II) terephthalate and DNA and preparation of DNA electrochemical sensor. J. Inorg. Biochem., v.99, n.12, p.2340-2347, 2005.

Received for publication on $04^{\text {th }}$ February 2009 Accepted for publication on $13^{\text {th }}$ January 2010 